\title{
Power Struggles in the Remembering of Historical Intergroup Conflict: Hegemonic and Counter-Narratives About the Argentine "Conquest of the Desert"
}

\section{Alicia Barreiro, Cecilia Wainryb and Mario Carretero}

\section{INTRODUCTION}

In this chapter, we examine laypeople's narratives about historical processes, collectively constructed, transacted, and transmitted in an effort to remember and make sense of past events involving conflicts between groups, and focus on the constitutive relations between hegemonic and counter-narratives. We rely on concrete examples of narratives about a specific process drawn from Argentine history, the "Conquest of the Desert," and examine what these narratives make visible, what they occlude and how they represent time, as a way to elucidate how the past is evoked, how the possibilities for a future are conceived, and how identities are negotiated and constructed. We focus, too, on the constitutive relations between hegemonic and counter-narratives. Our aim is to underscore some of the tensions and contradictions that arise in recollections and retellings of historical processes, as well as their implications for the construction of collective identities and intergroup relations.

\footnotetext{
A. Barreiro $(\bowtie) \cdot$ C. Wainryb $~ M$. Carretero

University of Buenos Aires, Buenos Aires, Argentina

e-mail: avbarreiro@gmail.com

(C) The Author(s) 2017

C. Psaltis et al. (eds.), History Education and Conflict Transformation, DOI 10.1007/978-3-319-54681-0_5
} 
The "Conquest of the Desert" implicated armed conflict as well as ongoing confrontation between groups. Thus, unavoidably, there are competing narratives about this historical process. The hegemonic narrative arose at the end of the 19th century to justify the territorial expansion and consolidation of the Argentine state in what used to be indigenous territory. This collective narrative is still expressed and supported by educational curricula and symbolic resources such as museums. The counter-narrative, traditionally endorsed by indigenous people, gained significant scholarly support only a few decades ago. The specific narratives we discuss in this chapter were gathered in a small Argentine city where descendants of the military men who had participated in the conquest and descendants of the immigrants who had occupied the conquered lands live together with descendants of the indigenous Mapuche people who used to occupy the land prior to the military campaign. Relying on these narratives, we consider the ways in which the hegemonic narrative becomes expressed in and supported by the exhibits of a local historical museum and the ways in which the counter-narrative supported by the local indigenous people stands in relation to the hegemonic narrative and constructs a complex group identity. To conclude, we reflect on the possibility of educational interventions aimed at reducing the tension between competing collective narratives and contributing to the development of intergroup dialogue and tolerance.

\section{Laypeople's Narratives About the Common Past, IDENTITy CONSTRUCTION, AND InTERgRoup RELATIONS}

Laypeople's narratives about historical processes stem from collective past experiences and group images shared in their common everyday experience (Jodelet 2003). Appeals to collective memory (Halbwachs $1925 / 1992$ ) become crucial to account for the way individuals remember history, that is, for how they remember a past that they did not themselves live. Hence, narratives about historical process are not created by individuals' direct experience, but are rather the "storage" of the collective memory of social groups, transmitted from one generation to the next one via the scientific production of historians, school teachings, mass media, and symbolic resources constructed by societies (Carretero 2011; Carretero and Kriger, 2011; Rosa 2006; Wertsch 2002). This everyday knowledge about the common past does not result only from transforming scientific knowledge into common sense knowledge; rather, 
it is a direct result of educational and school teaching interventions. Nevertheless, most people stop attending school some time at the end of their adolescence, but their knowledge about historical processes is kept alive in the collective memory and transmitted to future generations (Pennebaker et al. 2006).

Unsurprisingly, there are multiple versions about past events, depending on the varying perspectives and interests of the social or national groups implicated in the telling. This is important inasmuch as historical narratives influence how groups define their rights and duties, legitimize their political agreements, and adjudicate on the rightness or wrongness of their actions. Any account of the past has a political dimension, and all such accounts can be used to negate or legitimize the historical bases of claims made by social groups-claims that provide them with temporal continuity (Sibley et al. 2008). Hence, there necessarily is a constitutive tension between hegemonic narratives and counter-narratives. Hegemonic narratives convey the more stable, dominant, and consensual version of history; counter-narratives are defined by their opposition or resistance (whether explicit or implicit) to the dominant or hegemonic narratives. Thus, counter-narratives exist and make sense in relation to hegemonic narratives, and vice versa (Bamberg and Andrews 2004).

Common sense narratives about historical processes serve to support and defend a particular construction of social reality or to resist against hegemonic versions imposed by a powerful group. In our global world, multiple versions of reality coexist, and systems of knowledge are relatively heterogeneous and unstable; therefore, possibilities for critique, argumentation, and discussion abound (Barreiro et al., 2017). In general, people supporting hegemonic narratives are aware of the counterversion, and people who put forth counter-narratives are familiar with the hegemonic forms. In an important sense, and given the relational character of narratives, hegemonic and counter-narratives not only coexist side by side but penetrate each other, informing, arguing, and questioning. This complexity affects not only the narratives that are told; within both dominant and subjugated groups, individuals experience and reproduce these tensions. Hence, the conflicts between differentindeed, contradictory-versions of the same historical process can coexist in everyday life in the same social group, resulting in a state of cognitive polyphasia (Barreiro 2013; Duveen 2007; Jovchelovitch 2008; Moscovici 1961; Wagner et al. 2000). As will be discussed below, the state of cognitive polyphasia may be manifested at the collective level, such as in the 
construction of symbolic resources, as well as on the individual level, as expressed in the discourse of individual people.

Another way to think about the power struggles that become manifested in the construction of narratives about the past is to consider the process by which meanings are negotiated in dialogical relations among people and social groups. The social asymmetries of speakers often lead to certain representations not being recognized (Barreiro and Castorina 2016), thereby constraining the meaning-making processes. The meanings that prevail in this struggle between representational fields become positive representational elements included in the competing narratives. Other features-those that challenge and threaten the dominant perspective-are often excluded and become what has been labeled "nothingness" (Bang 2009; Barreiro and Castorina 2016), remaining as the dark or unacknowledged side of the positive elements represented in the narratives. This absence stems from a constructive process to cope with uncanny social objects or meanings. Nevertheless, those ignored elements of historical narratives perform a constitutive function in their genesis, as they can be constructed precisely because some elements are excluded.

Finally, it is also important to recognize that narratives about historical processes are relevant to identity development, especially to the construction of a sense of collective or group identity. Historical narratives tell group members who they are, where they are from, and where they are going (Sibley et al. 2008). In this way, individuals identify themselves as members of a group that has constructed an image of itself in the context of both collectively lived experiences and agreed-upon values. As has been abundantly shown, people's social identity is constructed based on the relative categorization and valuing of members of different social groups (Abrams et al. 2001; Ellemers et al. 2002; Tajfel and Turner 1986; Postmes and Branscombe 2010). In general, individuals strive to preserve a positive self-view and consider their ingroup more positively than the outgroups (Deaux and Martin 2003). Thus, individuals' understandings of social phenomena, such as historical events, depend more on how these events affect their sense of identity than on the actual facts or available evidence (Ellemers et al. 2002). Importantly, as social groups construct their own discourse about the social world, they also adapt to or resist other groups' discourse. To know the outgroup's discourse is to know how those individuals think of "us"; in other words, such discourse makes one aware of the existence of alternative representations of 
the self (Gillespie 2008). The representations of the different perspectives about ourselves are an important dialogical sub-part of our identity and allow individuals to deal with the plurality of representations about themselves. These alternative representations are attributed to other people and become evident when someone expresses the phrases "they think" or "they claim" or "they say."

\section{Conflicting Narratives in Argentine Remembering OF THE "CONQUest OF THE DEsERT"}

The Conquest of the Desert was a military campaign carried out by the Argentine state at the end of the 19th century (1874-1885), wherein the military made inroads into territories that had been up to then inhabited by indigenous groups. This period of territorial expansion and national organization involved (and, indeed, relied on) the massacre and enslavement of indigenous communities. Thousands were exterminated and many more sold into slavery to the new landowners. Survivors were forced to negate or ignore their culture and assimilate to the conquerors' culture, effectively becoming invisible as a social group (Del Río 2005; Halperin Donghi 1995). Their invisibility persisted over many decades (Gordillo and Hisrch 2010; Valko 2012) as the Argentine national identity consolidated as largely "white" or "European" (Carretero and Kriger 2011).

In the last few decades, various indigenous communities in Argentina gained some recognition, including formal status for their group rights, even as they remained deeply affected by poverty, racism, and social exclusion (Sarasola 2010). Although counter-narratives first emerged from within the indigenous community, nowadays they have been legitimized by historiography and other scientific disciplines (e.g., Bayer 2010; Briones 1994; Halperin Donghi 1995; Novaro 2003). Indeed, scientific accounts have challenged the hegemonic version of the narrative about the "Conquest of the Desert" that is expressed in school textbooks and monuments - a narrative that portrays the Argentine military as heroically working to subdue the violent and uncivilized tribes, thereby contributing to the organization and consolidation of the Argentine state and nation. In its stead, this counter-perspective brought to the fore the massacre and abuses carried out by the military against indigenous groups. 
The tension between conflicting narratives constitutes a state of cognitive polyphasia in the collective remembering of this historical process (Barreiro et al. 2016, 2017). The narrative about the glorious military campaign that consolidated Argentine sovereignty upon its current national territory works to create and support a sense of national identity (Carretero 2011); therefore, questioning such a narrative is deeply threatening. Nevertheless, there is also a collective awareness of the tragic history of the indigenous people, so individuals cannot simply deny these facts. Thus, both narratives become manifested in symbolic recourses such as history curricula, monuments, or names of streets, without maintaining a coherent relation between them. In this way, a state of cognitive polyphasia operates on Argentine collective memory, as a strategy to preserve their positive national identity and avoid collective guilt about their nation's actions, while at the same time recognizing the injustices suffered by indigenous people and representing a "politically correct" version of the national past (Barreiro et al. 2016). For example, many central provincial capitals throughout Argentina feature large equestrian statues commemorating General Roca, the chief commandant of the military campaign, that are ridden with graffiti saying "killer," "genocide," or "indigenous people are alive." Such vandalized monuments express the coexistence of two opposite versions of the past. Another example of the state of cognitive polyphasia is given by research (Barreiro et al. 2016; Sarti and Barreiro 2014) showing that although many Argentine adolescents and young adults are aware that indigenous people were massacred in the historical past, they fail to recognize the military campaign was carried out by the Argentine state and, erroneously, attribute it to "the Spaniards colonizers."

Importantly, the hegemonic narrative about the Conquest of the Desert denies not only the Argentine state's responsibility for the injustices suffered by indigenous people in the past, but also the existence of indigenous communities in the Argentine territory in the present, by constructing the story in such a way that one might think that all the indigenous people have been killed. Many studies (Gordillo and Hirsch 2010; Nagy 2014) have shown that the indigenous groups currently living in Argentina, and specifically in the province of Buenos Aires where more than $30 \%$ of the indigenous population resides, are still largely invisible. Moreover, the few symbolic recourses dedicated to recognizing the indigenous people, such as monuments or images in textbooks, tend to present their identity as homogenous and anachronistic. 
Stereotypic representations of indigenous people constitute the basis for prejudice (Ungaretti et al. 2015; Ungaretti and Müller, forthcoming). Furthermore, inasmuch as individual members of indigenous groups today fail to comply with the expectations of what an indigenous individual should look or act like, such stereotypic representations are also used to deny the indigenous identity in the present day.

\section{Constructing Group's Past in the Midst of Intergroup CONFLict}

From year 2013 to 2015, we carried out an ethnographic study to explore the varying narratives about the "Conquest of the Desert" in a small city, located in the southern region of the province of Buenos Aires. In this city, the descendants of the founding militaries and European immigrants who arrived at the beginning of 20th century to settle the "conquered" lands live alongside descendants of the indigenous Mapuche community who inhabited that territory before the conquest. In this chapter, we focus our analysis, first, on the hegemonic narrative as conveyed by the exhibitions of the local historical museum and, next, on the indigenous counter-narrative as registered during informal meetings and conversations with members of the local Mapuche community.

\section{The Hegemonic Narrative Expressed in the Local Museum's Exhibits}

The various rooms that articulate the exhibits of the local historical museum follow a traditional organization (Asensio and Pol 2012). Visitors are supposed to observe valued objects meant to reveal a narrative about the past, framed in terms of political events, world affairs, and national heroes. As is the case in many other Latin American historical museums (Gonzáles de Oleaga 2012), the hegemonic narrative in this local museum is presented as one-dimensional: Historical objects are presented as though they could narrate history in and of themselves. The sense of interpretation-which is essential to any historical texts-is not made visible to the visitor (Bennett 1998).

The sequence of the various rooms that constitute the exhibit is supposed to follow a chronological order. The exhibit begins with a room dedicated to pre-historical times, followed by another commemorating the indigenous people who inhabited the region. In this "indigenous 
room," visitors find a horse, tools used to make food, traditional indigenous cloths, some indigenous weapons, and several pictures of indigenous people dressed in traditional attire. The more antique objects exhibited there correspond to the time of the "Conquest of the Desert," but there is no explicit mention of such historical process in the exhibit. In addition to the enormous chronological gap between the previous room dedicated to pre-historical times and this one, the objects featured in this room include some pertaining to the end of the 19th century and others that refer to famous local indigenous people who died as recently as a few decades ago. In this sense, this room represents a time loop confusing past and present and joining very different moments of the local history. Across from the "indigenous room," visitors find a "colonial room" dedicated to the Conquest of America by Spaniards in the years 1492-1816, where the everyday life in the Argentine colony is depicted without any trace of indigenous people.

The sequence of the rooms in the museum seems to indicate a narrative wherein indigenous people inhabited the region after pre-historical times and until the arrival of the Spaniards, who colonized America. This narrative implicitly suggests that indigenous people disappeared because of the Spaniards' colonization. Unsurprisingly, this narrative is very similar to the one told by Argentine adolescents and adults (Barreiro et al. 2016; Sarti and Barreiro 2014), who hold the Spaniards responsible for the killing of the indigenous people while ignoring the role played by the Argentine nation-state.

While touring the "indigenous room" in the museum, we happened to observe a visit of a kindergarten classroom with their teacher. ${ }^{1}$ Below we reproduce a fragment of our record of the teachers' explanations, which help illustrate the looping between past and present in the hegemonic discourse about indigenous culture, as well as the ensuing anachronic representation of indigenous identity:

[...] all these objects that we are seeing here show how many different things the indigenous people used to have and used to do. They used to have a flag, they used to take care of their children, they used to prepare their own food. They also used to have a thanksgiving ceremony that was called nguillatun, because they were a very grateful people.

In fact, all the objects and activities mentioned by the teacher still exist and are part of today's indigenous culture. However, the teacher's 
explanations were all articulated in the past tense, leading children to believe that indigenous people and their culture no longer exist.

This teacher's discourse as well as the sequence of rooms in the museum works so as to deny the existence of a people who still live in their very city and all across the country. Their existence becomes "nothingness," and their identity is constructed anachronically, fixed in the past without considering its possible and actual development through time. Then, given that today's indigenous people cannot be easily distinguished from the other inhabitants of Argentina because they look the same, wear the same clothing, and use the same technology, they are considered "not real indigenous people" and "opportunists who only care about their roots because they want to receive a pension or restitution money from the government" (Barreiro et al. 2016; Nagy 2014). In this way, the stereotype of the indigenous people supported by the hegemonic narrative contributes to continued and heightened prejudice against them.

Altogether, the local museum's exhibit promotes one version of history and presents it de facto as the only possible version. In this way, this local history museum (as many other similar museums throughout Argentina and other Latin American countries) legitimizes the hegemonic version of the past by showing it as the unquestionable and accurate reflection of achievement of scientific research (González de Oleaga 2012). The traditional museum artifice does not prompt visitors to question who decides what should be displayed, who speaks in the name of the nation, or what is told versus silenced (Macdonald 1998). These questions, however, are crucial to unveil and make visible the power conflicts expressed-or silenced-in the museum's exhibit.

Another interesting aspect of the museum is that it does not feature a room dedicated explicitly to the "Conquest of the Desert." Rather, the biggest and most central room is the one dedicated to the foundation of the city. What is left unsaid, however, is that the foundation of this specific city (and other similar cities) happened as a direct consequence of that historical process. In this room, visitors can observe a main red wall that proudly features three Remington rifles. And yet, there is no explanation concerning what these rifles were used for, or why they are so important for national and regional history. According to the indigenous counter-narrative, the deadly power of these guns made it possible for the Argentine military forces to carry out the genocide of their people. Thus, to proudly exhibit these guns may have the shocking effect of denying their condemnable role in the conquest and ensuing genocide. 
It should also be noted that the construction of an exhibit dedicated to commemorating the guns used during the conquest implies a deeply insensitive and offensive attitude vis-à-vis the feelings of indigenous people who might visit the museum and encounter a room that celebrates the guns that killed their ancestors. This is not a minor oversight, given that the museum is located in (and tells the story of) a city that counts large numbers of indigenous people as their long-standing residents. In effect, this may work as yet another way in which the current existence of indigenous people is denied-inasmuch as no consideration is given to them as a possible audience. Perhaps in some ways, this both reflects and also tends to reinforce the hegemonic view that "all indigenous people were killed," which conveniently makes the need for justice and restitution unnecessary.

It is noteworthy that hegemonic narratives do not tend to include a dialogue with alternative representations. Rather, when a dominant social group becomes aware of the presence of an alternative representation, as might be the case with the ongoing existence of indigenous people, their members develop different semantic barriers (Gillespie 2008) in their discourse to defend their own representations, keeping them away from the dialogical exchange. Indeed, the use of the past tense in the teacher's discourse and the negation of the ongoing existence of indigenous people associated with the construction of an anachronic indigenous identity may be considered as instances of protective semantic barriers.

Finally, in analyzing the power of the official narrative as expressed in the museum's exhibits it is necessary to consider the way the national Argentine identity is presented. From an intergroup relation perspective, the narratives about "who we are" that constrain the formation of an imagined community are constructed in relation to narratives about "who they are." In this museum, the Argentine identity is presented across the various rooms as continuous and stable, beginning with the Spanish colony and until the foundation of the city where the museum is located. Thus, the essence of the Argentine identity is presented as arising after the "indigenous times." Furthermore, the Argentines, as a people, are considered as homogenous and as represented by homogenous social groups that still hold a dominant role in Argentine society: the militaries and the political class, all of whom deny the current existence of the ingenious community. 


\section{Counter-Narratives and Mapuche's Resistance}

As mentioned above, in the last few decades various scientific disciplines disseminated in the lay population a counter-narrative about what happened during the "Conquest of the Desert." And yet, this counter-narrative is not new; it has been supported by indigenous communities since the end of the 19th century. Here, we present transcripts of records from our visit to the local Mapuche community. These help illustrate the counter-narrative upon which this community has constructed its identity and based their claims for justice and reparation against the Argentine state. We begin with a transcript from a formal document, given to us by one of the main representatives of the Mapuche community, which had been presented before the Indigenous Parliament (a group that comprises representatives from diverse indigenous communities):

... I am the great-grandchild of the Chief of the Mapuches Pampa. In the year 1878, he was the first to suffer the brunt of the brutal Argentine invasion of the territories of our people, known euphemistically as the Conquest of the Desert [...] The Argentine army, armed with the best weapons purchased abroad, decimated my people: men, women, and children. The survivors were spread around. Men were sent to jail or forced to do hard labor, women were sold or given away like property, some to the military, some as domestic workers to the wealthy families in the cities. Article 4 of the Treaty of June 14, 1873 stated: 'The national government makes a commitment to respect the lands occupied today by the tribes and to never invade them, so that they can live peacefully with the protection of the government'. But my people were sold into slavery. In this process we lost everything [...] Today we are 200 families and we have come together, about 1000 people, and there are still many more spread around the country. How can we live with dignity and preserve our community without a land, when the promises and commitments made to us in the Treaty of June 14, 1873 have not been fulfilled?

The differences between the main contents expressed in this counternarrative and its hegemonic counterpart discussed above are noteworthy. First, in this narrative the Conquest of the Desert is presented not as a war or conflict between groups with equal power and competing interests but as an unjust invasion of the indigenous lands carried out by the Argentine government. This invasion is thought of as unjust inasmuch as it had violated treaties entered into with the indigenous 
tribes-something not even acknowledged in the hegemonic version. Furthermore, this counter-narrative does not talk about a genocide or extermination of the indigenous people; rather, it tells the story as one involving a diaspora that resulted in the loss of the unity among indigenous groups, in the loss of their property and territories, and their being sold into slavery. It is worth noting that slavery was already illegal at the time, as it had been abolished in Argentina in 1813. Another element, less evident but not less interesting, is the usage of time in this narrative. The author of the text starts out by affirming his identity and his claims in the past, based on his being the descendant of the tribe's chief, the violation of previous treaties, and more broadly based on facts that took place over 100 years earlier. Nevertheless, he then moves on to the present, as he mentions the current and ongoing situation of indigenous families and even alludes to the future as he articulates the impossibility of imagining a life with dignity. In this way, the author appeals to the past in an effort to justify his present claims and explain the impossibility of a future for his people.

Also, this narrative presents past events as the direct cause of the present and ongoing social exclusion experienced by indigenous people in Argentine. In an important sense, the political implications of this narrative become quite evident: Inasmuch as this version makes visible to the Argentine people elements that were occluded from the hegemonic narrative, the Argentine government is called to admit past wrongdoings it had committed against the indigenous communities and find ways to provide reasonable restitution-thereby profoundly subverting the political and social status quo.

For the purpose of analyzing the constitutive relations between the counter-narrative and its hegemonic counterpart, it is important to understand how the former constructs the indigenous identity. As noted earlier, the author considers his identity based on his past and appeals to his being a direct descendant of the indigenous chief. But he also moves on to referring to "we" and "us" in order to articulate a continuity between "his" people that was decimated during the conquest and the ongoing experience of the indigenous community. In some respects, time seems to freeze, as indigenous people are presented as a homogenous group that is preserved over the centuries. This kind of rhetorical move has been identified as characterizing other historical accounts (Carretero and Van Alphen 2014), and in that respect, it may be a common feature of how groups constitute their group identity based on 
some sort of myth about their origins (Sibley et al. 2008). And yet, this direct and static relation between the indigenous people in the present and those of the past is not always preserved. On the contrary, the relation between the past "we" and the present "we" is often ridden with tensions, as shown in the following record of a meeting we held with a female member of the indigenous community during one of our visits.

This woman started explaining that she taught traditional arts and pottery to members of her community, and then clarified: "well, I don't know if I taught them how to make pottery, I think they have it in their DNA, so they intuitively knew how to do it". Later, as she described her own life, she mentioned: "I chose to live in a house with an adobe floor because I wanted to find my identity, I had to have that experience. And my dad yelled at me, he said: 'I worked so hard to have a real floor, and you want to keep looking backwards'. But I feel that to move forward I have to keep looking backwards, I have to know what my identity is". And later in the conversation she explained that she teaches traditional pottery but she wants the experience of making pottery to have a real meaning; she wants her students to begin thinking up new designs that reflect their current experience and have meaning for them in the present. And she said: “... people always think that being part of the indigenous community means that one has to continue doing things the way they were done in the past, they don't understand that we exist today and that our art belongs in the present." And then she recalled that in preparing a piece of pottery for an assignment, one of her young students shaped the piece as 'Mickey Mouse' because this gave voice to something that was known and valuable to this girl in the present time. Her student's choice, she told us, gave her pause and left her pondering. Another member of the community who was present at that meeting intervened at that point and said "people are always surprised when we tell them we have cellphones, as though Indians ${ }^{2}$ should just have boleadoras". Everyone burst out laughing.

At the beginning of this meeting, the art teacher defines the indigenous identity in terms of heredity (as she refers to "their DNA") and in relation to past traditions (as when she wanted a traditional adobe floor to feel connected to her traditional roots). The indigenous identity is thus constructed in an anachronic way, not unlike the way it was presented in the official version, as frozen in time. Nevertheless, this woman also articulates a more dynamic, less frozen, sense of identity, as when she wants her students to transform the traditional forms of art and make them their own, in the present. In this regard, she seems to convey that 
the sense of continuity with the culture and traditions of her ancestors does not prevent their transformation-as in her call for using traditional art methods to construct modern or current symbols.

In our view, the various discourses of members of the indigenous community seem to suggest the coexistence of two contradictory representations of their own indigenous identity - two representations that are in tension with one another. One is anachronistic, fixed in the past, and consistent with the prevalent hegemonic discourse. The other is a more dynamic version, one that permits members of the community to imagine different ways of being members of this community, ways that change over time. We propose that this state of cognitive polyphasia gives voice to two needs on the side of indigenous people. One is the need to constitute themselves as a social group, to be recognized by the other, and to legitimize their claims for justice against the Argentine state. In an effort to establish a linear continuity with their people from the past, as (in the way it would be articulated by the hegemonic narrative) "real indigenous people," they resort to taking in and adopting features of the alternative hegemonic representations. The other need is for their identities to reflect the fact that they live real lives in the presentlives that have modified their traditions; they need to think of themselves in less frozen ways, as members of an indigenous community who are entitled to modify themselves and be indigenous in some ways different from the ways their ancestors were indigenous. In some respects, then, their stories appropriate aspects of the alternative representations of the indigenous identity that are articulated by the dominant hegemonic narrative-this may serve for them to gain recognition as a community in the eyes of the dominant groups. At the same time, their stories also call for a newly elaborated version, their own perspective on their culture-a piece that has been invisible and, indeed, negated, within the hegemonic framework. As the two women burst out laughing when they say "people are always surprised when we tell them we have cellphones, as though Indians should just have boleadoras," their mocking of the alternative hegemonic representation reflects what Gillespie (2008) has labeled bracketing, a discursive strategy that conveys both acknowledgment and critical resistance. Nevertheless, their discourse makes it evident that while they recognize that version of themselves as not their own version but as the view that others have of them and mock it, they also, at times, grab on to and appropriate that representation, or pieces of it. 


\section{Conclusions}

In this chapter, we have discussed the differences and similarities between the contents of hegemonic and counter-narratives related to the Conquest of the Desert and the tensions and conflicts between the two, as each version positions itself as the objective truth about what actually happened. The hegemonic narrative negates the conflict between the two groups in the present, by rendering the indigenous group invisible and nonexistent and by narrating their identity in anachronistic ways. As a result, it delegitimizes indigenous claims for recognition and reparation and works to protect and reproduce the social order. The counter-narrative explicitly postulates the existence of a conflict between the indigenous community and the Argentine state-a conflict that started out in the past and persists in the present, inasmuch as past wrongs have not been acknowledged and repaired, group rights have not been guaranteed, and injustices and exclusion persist in the present time.

And yet, we have also underscored that hegemonic and counter-narratives are not homogeneous and stable. Tensions and contradictions abound both between and within narrative discourses. Indeed, we have shown that specific narrative elements may serve distinct functionswhether it is to establish or challenge continuity, to resist characterizations suggested by alternative representations, or to avoid responsibility and deny claims for reparations. On the one hand, the hegemonic narrative promotes a positive view of the Argentine national identity by acknowledging the goodness of the original inhabitants ("they used to take care of their children, they used to prepare food... they used to be very grateful people") and attributing their extinction to the colonizing process initiated by the Spaniards (as manifested in their disappearance from the historical timeline in the museum) without ever acknowledging the actions of the Argentine state in the past and rendering invisible their existence in the present. On the other hand, the counter-narrative creates a continuity between past, present, and future by establishing its inevitable links with the Argentine state and features a noticeable tension between the need to assert their identification with their ancestors and gain recognition from the dominant group, while also allowing for change and transformation in their midst.

Our thinking about the process of remembering and narrating historical events allows us to draw implications for designing educational interventions aimed at modifying the extant narratives in such ways so as to 
promote the betterment of the indigenous communities in Argentina. It must first be noted that any such attempts at intervention cannot take place exclusively at the individual level because both hegemonic and counter-narratives are manifested and supported by collective symbolic resources. Hence, any intervention must attempt a broad or global transformation of how both past processes and the ongoing indigenous situation are discussed. Also, it would be critical to allow for multiple competing versions of events to coexist and dialogue, challenging, informing, and enriching one another. And yet, such transformation is not easy to accomplish inasmuch as alterations in collective narratives have direct impact on individual and group identity and are therefore resisted consciously and unconsciously.

In this vein, it is also important to note that we are not proposing an intervention at the informational or even conceptual level. Changes in collective narrative discourse are unlikely to come about merely as a result of new facts or evidence-it is the representation and interpretation of facts, the meanings made of facts that are in dispute. The notion of state of cognitive polyphasia suggests that people develop strategies to deal with conflicting information without changing their beliefs and interpretations. It is the state of polyphasia, rather than mere information, which must be addressed.

But how does one go about doing this? The goal is not necessarily to support or reinforce one or another version of historical events. Rather, it would be important to support students in acquiring and utilizing the skills of a lay historian: searching and selecting for sources of historical evidence, the systematic weighing and comparing of evidentiary facts, so as to construct hypotheses about the phenomenon at hand, and develop the willingness to critically revise their conclusions.

\section{Notes}

1. The social roles of all the people mentioned in this chapter had been slightly modified to preserve the anonymity of their identities.

2. Although "Indian" is not the acceptable term to refer to indigenous people because it builds on the mistaken assumption of the first Spaniards colonizers (i.e., that they had arrived to India) and denies their true identity, we did observe that members of the local indigenous community often use this term colloquially to refer to themselves without considering it offensive. It is, however, typically considered offensive or derogatory when used by non-indigenous people. 
Acknowledgments This work has been supported by funding from the research projects PICT-2012-1594 and PICT-2014-1003 (FONCyT-Argentina), and a grant from the Latin American Studies, University of Utah.

\section{REFERENCES}

Abrams, A., Wetherel, M., Cochrane, S., Hoog, M., \& Turner, J. C. (2001). Knowing what to think by knowing who you are: Self-categorization and the nature of norm formation, conformity and group polarization. In M. A. Hogg \& D. Abrams (Eds.), Intergroup relations. Essential readings (pp. 270288). New York: Taylor \& Francis.

Andrews, M. (2004). Opening the original contributions. Counter-narratives and the power to oppose. In M. Bamberg \& M. Andrews (Eds.), Considering counter-narratives: Narrating, resisting, making sense (pp. 2-6). Philadelphia: John Benjamins.

Asensio, M., \& Pol, E. (2012). From identity museums to mentality museums: Theoretical basis for history museums. In M. Carretero, M. Asensio \& M. Rodriguez Moneo (Eds.), History education and the construction of national identities (pp. 257-268). Charlotte, NC: Age Publishing.

Bamberg, M., \& Andrews, M. (2004). Introduction to the book. In M. Bamberg \& M. Andrews (Eds.), Considering counter-narratives: Narrating, resisting, making sense (pp. IX-X). Philadelphia: John Benjamin.

Bang, J. (2009). Nothingness and the human umwelt. A cultural-ecological approach to meaning. Integrative Psychological and Behavioral Science, 43, 374-392.

Barreiro, A. (2013). The appropriation process of the belief in a just world. Integrative Psychological and Behavioral Sciences, 47, 431-449.

Barreiro, A., \& Castorina, J. A. (2016). Nothingness as the dark side of social representations. In J. Bangs \& D. Winther-Lindqvist (Eds.), Nothingness (pp. 69-88). New Jersey: Transaction Publishers.

Barreiro, A., Castorina, J. A., \& Van Alphen, F. (2017). Conflicting Narratives about the Argentinean 'Conquest of the Desert': Social Representations, Cognitive Polyphasia, and Nothingness. In M. Carretero, S. Berger \& M. Grever (Eds.), Palgrave Handbook of Research in Historical Culture and Education (pp. 373-389). London, UK: Palgrave Macmillan.

Barreiro, A., Wainryb, C., \& Carretero, M. (2016). Narratives about the past and cognitive polyphasia remembering the Argentine "Conquest of the Desert". Peace \& Conflict. Special Issue "Memory and Conflict", 22(1), 44-51.

Bayer, O. (2010). Historia de la crueldad argentina. (History of the Argentinean cruelty). Buenos Aires: El Tugurio.

Bennett, T. (1998). Speaking to the eyes: Museums, legibility and the social order. In S. Macdonald (Ed.), The politics of displays: Museums, science and culture (pp. 25-36). London: Rutledge. 
Briones, C. (1994). Con la tradición de todas las generaciones pasadas gravitando sobre la mente de los vivos. Usos del pasado e invención de la tradición. RUNA, 21, 99-129.

Carretero, M. (2011). Constructing patriotism. Charlotte, North Carolina: Sage.

Carretero, M., \& Kriger, M. (2011). Historical representations and conflicts about indigenous people as national identities. Culture \& Psychology, 17(2), $177-195$.

Carretero, M., \& van Alphen, F. (2014). Do master narratives change among high school students? A characterization of how national history is represented. Cognition and Instruction, 32(3), 290-312.

Deaux, K., \& Martin, D. (2003). Interpersonal networks and social categories: Specifying levels of context in identity processes. Social Psychology Quarterly, $66(2), 101-117$.

Del Río, W. (2005). Memorias de la expropiación. Sometimiento e incorporación indigena en la Patagonia (1872-1943). Ed. Universidad de Quilmes.

Duveen, G. (2007). Culture and social representations. In J. Valsiner \& A. Rosa (Eds.), The Cambridge handbook of sociocultural psychology (pp. 543-559). Cambridge: Cambridge University Press.

Ellemers, N., Spears, R., \& Doosje, B. (2002). Self and social identity. Annual Review of Psychology, 53, 161-186.

Gillespie, A. (2008). Social representations, alternative representations and semantic barriers. Journal for the Theory of Social Behaviour, 38(4), 375-391.

Gonzáles de Oleaga, M. (2012). Historical Narratives in the Colonial, National, Ethnic Museum of Argentina, Paraguay and Spain. In M. Carretero, M. Asensio \& M. Rodriguez Moneo (Eds.), History education and the construction of national identities (pp. 239-256). Charlotte, NC: Age Publishing.

Gordillo, G., \& Hirsch, S. (2010). La presencia ausente: invisibilizaciones, políticas estatales y emergencias indígenas en la Argentina. En G. Gordillo \& S. Hirsch (Comps.) Movilizaciones indigenas e identidades en disputa en la Argentina (pp. 15-38). Buenos Aires: La Crujía.

Halbwachs, M. (1925/1994). Les cadres sociaux de la mémoire. Paris: Albin Michel.

Halperin Donghi, T. (1980/1995). Una Nación para el Desierto Argentino. Buenos Aires: CEAL.

Jodelet, D. (2003). Pensamiento Social e Historicidad. Relaciones, 93(24), 98-113.

Jovchelovitch, S. (2008). The rehabilitation of common sense. Social representations, science, and cognitive polyphasia. Journal for the Theory of Social Behavior, 38(4), 431-448.

Macdonald, S. (1998). Exhibitions of power and powers of exhibition: An introduction to politics of display. In S. Macdonald (Ed.), The politics of displays: Museums, science and culture (pp. 1-24). London: Routledge. 
Moscovici, S. (1961). La psychanalyse son image et son public. París: PUF.

Nagy, M. (2014). Estamos vivos. Historia de la comunidad indigena Cacique Pincén, provincial de Buenos Aires (siglos $X I X-X X)$. Buenos Aires. Antropofagia.

Novaro, G. (2003). Indios" “Aborígenes" y "Pueblos originarios". Sobre el cambio de conceptos y la continuidad de las concepciones escolares. Educación, Lenguaje y Sociedad, 1, 199-219.

Pennebaker, J., Paez, D., \& Deschamps, J. C. (2006). The social psychology of history: Defining the most important events of the last 10, 100, and 1000 years. Psicología Politica, 32, 15-32.

Postmes, T., \& Branscombe, N. (2010). Sources of social identity. En T. Postmes \& N. Branscombe (Eds.), Rediscovering social identity: Core sources. Psychology Press.

Rosa, A. (2006). Recordar, describir y explicar el pasado, ¿qué, cómo y para el futuro de quién? In M. Carretero, A. Rosa, \& M. F. Gonzáles (Eds.), Enseñanza de la historia y memoria colectiva (pp. 41-52). Buenos Aires: Paidós.

Sarasola, C. M. (2010). De manera sagrada y en celebración: Identidad, cosmovisión y espiritualidad en los pueblos indigenas. Buenos Aires: Biblios.

Sarti, M., \& Barreiro, A. (2014). Juicios Morales y memoria colectiva: narrativas de jóvenes sobre la "Conquista del Desierto". In J. A. Castorina \& A. Barreiro (Eds.), Representaciones sociales y prácticas en la psicogénesis del conocimiento social (pp. 141-156). Buenos Aires: Miño y Dávila.

Sibley, C., Liu, J., Duckitt, J., \& Khan, S. (2008). Social representations of history and the legitimation of social inequality: The form of historical negation. European Journal of Social Psychology, 38, 542-568.

Tajfel, H., \& Turner, J. C. (1986). The social identity theory of inter-group behavior. In S. Worchel \& L. W. Austin (Eds.), Psychology of intergroup relations. Chicago: Nelson-Hall.

Ungaretti, J., \& Müller, M. (forthcoming). Estudios sobre el prejuicio hacia diferentes grupos sociales. In A. Barreiro (Ed.), La construcción del conocimiento social y moral: representaciones sociales, prejuicio y relaciones con los otros. Buenos Aires: UNIPE.

Ungaretti, J., Etchezahar, E., \& Barreiro, A. (2015). Análisis de la escala de prejuicio sutil y manifiesto hacia indigenas, poster presented at I Congreso Nacional de Psicología. Argentine: San Luis. [unpublished].

Valko, M. (2012). Los indios invisibles del Malón de la Paz. De la apoteosis al confinamiento, secuestro y destierro. Buenos Aires: Continente.

Wagner, W., Duveen, G., Verma, J., \& Themel, M. (2000). "I have some faith and at the same time I don't believe in it"-cognitive polyphasia and culture change. Journal of Community and Applied Social Psychology, 10, 102-314.

Wertsch, J. (2002). Voices of collective remembering. Cambridge: Cambridge University Press. 


\section{Authors' Biography}

Alicia Barreiro is a Professor at the University of Buenos Aires and FLACSOArgentina. Besides, she is a Researcher at the National Council of Scientific and Technical Research. She studies moral and social development complementing developmental psychology approach with social representations theory, as well as collective memory and its role in determining the actual intergroup relations. She has published widely in international journals and published several book chapters. Recently, she co-authored with José Antonio Castorina and Floor Van Alphen "Conflicting Narratives about Argentinean 'Conquest of the Desert'. Representations, cognitive Polyphasia, and Nothingness" (Carretero, Berger and Grever, Palgrave Handbook of Research in Historical Culture and Education, Palgrave Macmillan forthcoming) and with José Antonio Castorina "Nothingness as the dark side of social representations" (Bang and WintherLindqvist, Nothingness pp. 69-88, Transaction Publishers 2016), and she edited the book "La construcción del conocimiento social y moral: representaciones sociales, prejuicio y relaciones con los otros" (Unipe, forthcoming).

Cecilia Wainryb is a Professor of Psychology at the University of Utah and the co-director of the Social Development Lab. Her research interests span moral, social and emotional development, and her work examines how children and adolescents construct meaning from moral transgressions and interpersonal and group conflict, and how such meanings contribute to the development of moral agency. She has studied these processes in community samples as well as with samples of youth growing up in the midst of war and political violence. Her studies combine interview data, narrative methods, conversation analyses and psychophysiological measures. She has published widely in international journals and has edited several volumes, including most recently "Talking about right and wrong: Parent-child conversations as contexts for moral development" (Cambridge University Press 2014, with H. Recchia) and "Trauma, psychopathology, and resilience among child soldiers around the world" (Routledge 2014, with P. Kerig).

Mario Carretero is a Professor of Cognitive Psychology at Autonoma University of Madrid, Spain, where he was Dean of the Faculty of Psychology, and Researcher at FLACSO, Argentina. He has carried out an extensive research on history education from both cognitive and sociocultural approaches. He has published in Journal of the Learning Sciences and Cognition and Instruction. His last books are History Education and the Construction of National Identities (2012) (co-ed.) and Constructing Patriotism (funded by the Guggenheim Foundation) (2011). He has been Santander Visiting Scholar at the David Rockefeller Center for Latin American Studies of Harvard University (2009) 
and Bliss Carnochan Visiting Professor at the Humanities Center of Stanford University (2011). His present research interests have to do with an interdisciplinary attempt to study history education issues as it can be seen in Palgrave Handbook of Research in Historical Culture and Education (2017) (co-edited along with S. Berger and M. Grever).

Open Access This chapter is licensed under the terms of the Creative Commons Attribution 4.0 International License (http://creativecommons.org/licenses/ by $/ 4.0 /)$, which permits use, sharing, adaptation, distribution and reproduction in any medium or format, as long as you give appropriate credit to the original author(s) and the source, provide a link to the Creative Commons license and indicate if changes were made.

The images or other third party material in this chapter are included in the chapter's Creative Commons license, unless indicated otherwise in a credit line to the material. If material is not included in the chapter's Creative Commons license and your intended use is not permitted by statutory regulation or exceeds the permitted use, you will need to obtain permission directly from the copyright holder.

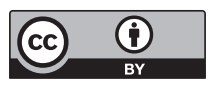

